\title{
PRINSIP DASAR RANCANG BANGUN EKONOMI SYARI'AH PERSPEKTIF OTORITAS PENGADILAN AGAMA
}

\author{
Oleh: \\ Jamaluddin *
}

\begin{abstract}
Abstrak
Artikel ini membahas tentang bagaimana para pakar ekonomi syariah merumuskan rancang prinsip dasar rancang bangun eknomi syariah. walaupun ada beberapa perbedaan dalam struktur dan tata urutanya, tetapi secara subtansinya sama dengan yang lainya. Ada beberapa prinsip dasar terhadap rancang bangun ekonomi syari'ah. Muhammad mengatakan bahwa bangunan ekonomi syari'ah diletakkan pada 5 (lima) fondasi, yaitu : Ketuhanan (Ilahiah), keadilan (al-Adl), kenabian (anNubuwah), pemerintahan (al-Khalifah), dan hasil/kuntungan (al-Ma'ad). Kelima fondasi tersebut dapatnya menjadikan aspirasi dalam menyusun teori-teori ekonomi syari'ah
\end{abstract}

Kata Kunci: Prinsip Dasar Rancang Bangun Ekonomi Syariah, Otoritas Peradilan Agama

\section{Pendahuluan}

Misi kerasulan di bidang ekonomi syari'ah sesungguhnya sudah dimulai sejak zaman Nabi Adam as. pada awal menempati bumi ini sebagai orang pertama. Sejak itulah muncul masalah ekonomi dan tentang kebutuhan hidup manusia (ekonomi) yang paling vital, yaitu masalah Pangan, Sandang dan Papan. Sebagaimana firman Allah dalam surat al-Baqarah, 36 sebagai berikut

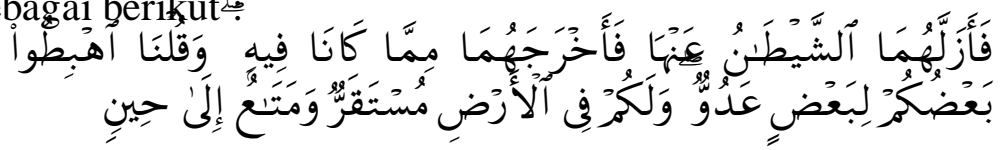

\footnotetext{
${ }^{*}$ IAIT Kediri
}

Volume 26 Nomor 1 Januari 2015 
Terjemahanya: "Lalu keduanya digelincirkan oleh syaitan dari surga itu dan dikeluarkan dari keadaan semula dan Kami berfirman: "Turunlah kamu sebagian kamu menjadi musuh bagi yang lain, dan bagi kamu ada tempat kediaman di bumi, dan kesenangan hidup sampai waktu yang ditentukan"1 (QS. Al-Baqarahm 36).

Oleh karena itulah beliaulah yang pertama kali memecahkan masalah ekonomi secara makro (macro ekonomic problem solving) dan kegiatan ekonomi yang dilakukanya merefleksikan fungsi kekhalifahan sebagaimana yang dikehendaki Allah swt. firman Allah dalam surat al-Baqarah, 30-33 sebagai berikut :

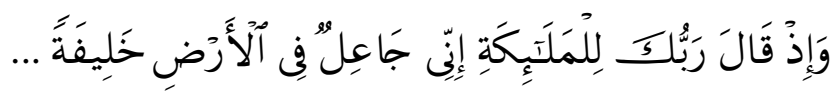

Terjemahanya: "Ingatlah ketika Tuhanmu berfirman kepada para Malaikat: "Sesungguhnya aku hendak menjadikan seorang khalifah di muka bumi. ..." 2 (QS. Al-Baqarah, 30-33)

Nabi Adam as. adalah mahaguru untuk solusi ekonomi (pangan), Nabi Idris as. dengan keahlianya sebagai penjahit yang profesional, itu berarti telah mencairkan problem ekonomi (sandang), Nabi Nuh as. dengan keahlianya membuat tempat berlindung dan perumahan sekaligus kendaraan (perahu), berarti telah menciptakan hak paten pertama untuk perkapalan dan membangun kembali perumahan (papan) setelah selamat dari banjir bandang dan kebanjiran.

Nabi Hud as. dan Sholeh as. melanjutkan rutinitas kegiatan ekonomi sebagaimana tiga Nabi sebelumnya. Nabi Ibrahim, Ismail dan Ishak as. menyiapkan infrastruktur ibadah Haji dan Umroh yang kemudian hari banyak mendatangkan devisa negara dan meramaikan perdagangan (Haji \& Umroh) di

${ }^{1}$ Departemen Agama RI., al-Qur'an dan Terjemahanya, (Jakarta: Tim Pengadaan Kitab Suci al-Qur'an, 1984), hlm.

2 Departemen Agama RI., al-Qur'an dan Terjemahanya, hlm. 
Prinsip Dasar Rancang Bangun... Oleh: Jamaluddin

Makkah dan Madinah ${ }^{3}$. Firman Allah dalam al-Qur'an surat alBaqarah, 125-128 sebagąi berikut :

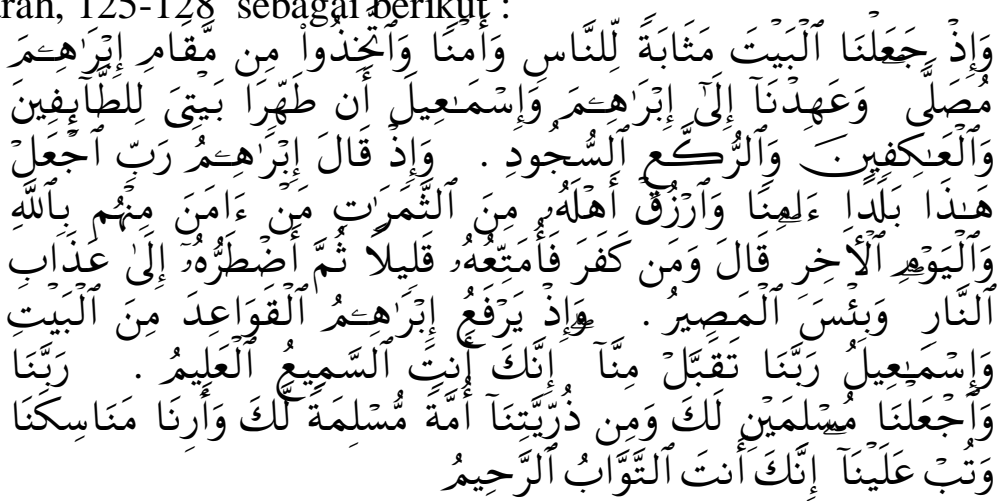

Terejemahnya: “Dan (ingatlah), ketika Kami menjadikan rumah itu (Baitullah) tempat berkumpul bagi manusia dan tempat yang aman. Dan jadikanlah sebahagian maqam Ibrahim tempat shalat. Dan telah Kami perintahkan kepada Ibrahim dan Ismail: "Bersihkanlah rumah-Ku untuk orangorang yang thawaf, yang i'tikaf, yang ruku' dan yang sujud". Dan (ingatlah), ketika Ibrahim berdoa: "Ya Tuhanku, Jadikanlah negeri ini, negeri yang aman sentosa, dan berikanlah rezki dari buah-buahan kepada penduduknya yang beriman diantara mereka kepada Allah dan hari kemudian. Allah berfirman: "Dan kepada orang yang kafirpun aku beri kesenangan sementara, kemudian aku paksa ia menjalani siksa neraka dan itulah seburuk-buruk tempat kembali". Dan (ingatlah), ketika Ibrahim meninggikan (membina) dasar-dasar Baitullah bersama Ismail (seraya berdoa): "Ya Tuhan Kami terimalah daripada Kami (amalan kami), Sesungguhnya Engkaulah yang Maha mendengar lagi Maha Mengetahui". Ya Tuhan Kami, Jadikanlah kami berdua orang yang tunduk patuh kepada Engkau

${ }^{3}$ M. Yusuf \& Wiroso, Pengantar Ekonomi dan Bisnis Syari'ah, Edisi 2, (Jakarta: Mitra Wacana Media, 2011), hlm. 1

Volume 26 Nomor 1 Januari 2015 
dan (jadikanlah) diantara anak cucu kami umat yang tunduk patuh kepada Engkau dan tunjukkanlah kepada kami cara-cara dan tempattempat ibadat haji kami, dan terimalah taubat kami. Sesungguhnya Engkaulah yang Maha Penerima taubat lagi Maha Penyayang"4 (QS. Al-Baqarah, 125-128).

Nabi Daud dan Sulaiman as. mempelopori ekonomi industri, dimana ia berdua mengaktifkan produksi baju besi (baju perang), furniture, peralatan rumah, proprti, perhiasan, jawatan pos dan industri pesawat terbang serta manajerial lainya, sebagaimana yang tertuang dalam surat Shad: 24 , surat al-Saba': 12-13, surat al-Anbiya': 80-82, surat an-Naml: 20-26.

Nabi Zakariya as. ahli di bidang pengelolaan hutan, produksi hulu dan hilir serta pengelolaan kayu. Nabi Isa as. ahli di bidang medis yang berarti orang pertama untuk usaha jasa Rumah Sakit.

Nabi Muhammad saw. mengatifkan perdagangan yang tangguh dalam arena persaingan globan dan mengajarkan persaingan sehat dan sebagai pemerintah dapat membangun sistem moneter yang maju, sistem pasar equilibtium, sisten transaksi dan akuntasi, sistem perseroan, perkongsian dan investasi.

Dengan demikian sesungguhnya keadaan dunia, bangsabangsa, adat-istiadat dan keyakinan tidaklah selalu mengikuti model dan sistem yang tetap, melainkan selalu berubah-ubah dari masa ke masa sesuai dengan situasi dan kondisi, selalu berpindah dari suatu keadaan berpindah kepada keadaan yang lain, hal ini sudah menjadi hukum alam (sunnatullah) dalam kehidupan manusia.

Aktivitas ekonomi sesungguhnya sejak Nabi Adam dan Siti Hawa diturunkan ke bumi oleh Allah swt. pada ratusan ribu tahun yang silam. Merekalah yang pertama kali melakukan kegiatan ekonomi dengan cara mengambil langsung dari alam (food gathering) guna memenuhi kebutuhan hidupnya, terutama yang menyangkut pangan, sandang dan papan.

${ }^{4}$ Departemen Agama RI., al-Qur'an dan Terjemahanya, hlm. 
Demikian juga eksistensi peradilan agama (di Indonesia) tidak dapat dipisahkan dengan peradilan yang lain pada umumnya, karena keberadaan peradilan agama merupakan sesuatu yang mutlak adanya (conditio sine quanon). ${ }^{5}$ Ia ada berbanding lurus dengan adanya Islam dan pemeluknya, maka disitu pasti ada lembaga peradilan, karena peradilan agama berfungsi sebagai lembaga yang akan menyelesaikan pesrengketaan di antara pemeluk agama Islam.

Hal tersebut tercermin dari preseden munculnya bentukbentuk penyelesaian sengketa yang terjadi pada masa Rasulullah saw. bahkan sudah nampak dalam bentuk lembaga pada masa sahabat dan sesudahnya, walaupun dalam bentuk dan corak yang sangat sederhana dan namanyapun juga berbeda-beda. Namun lembaga peradilan sejak masa klasik sampai sekarang eksistensinya tetap dibutuhkan oleh masyarakat Muslim di seluruh dunia, dimana mereka berada, tidak terkecuali di Indonesia.

Oleh karena itu eksistnsi perdailan agama di Indonesia sejak masa kerajaan, penjajahan, \& kemerdekaan (Orde Lama \& Orde Baru) sampai masa Reformasi bahkan masa yang akan datang, tidak terlepas dari sejarah panjang, eksistensi lembagaa peradilan agama Islam, dimana mata rantai yang tidak pernah terputus dari masuknya agama Islam di Indonesia.

\section{Pengertian Ekonomi Syari'ah}

Pengertian ekonomi syari'ah dan ilmu ekonomi secara singkat sangat berkaitan dengan ekonomi pada umumnya. Pendapat Paul Anthony Samuelson sebagaimana yang kutip oleh Ely Masykuroh, yang dimaksud dengan "ilmu ekonomi adalah ilmu yang membicarakan tentang studi mengenai cara-cara manusia dan masyarakat dalam menjatuhkan pilihanya, dengan tanpa menggunakan uang untuk menggunakan sumber-sumber produktif yang mempunyai kegunaan alternatif, untuk memproduksi barang dan mendistribusikanya serta untuk

5 Jaenal Arifin, Jejak Langkah Peradilan Agama di Indonesia, (Jakarta: PT Khaarisma Putra Utama, 2013), hlm. 1 
dikonsumsi, baik pada waktu sekarang maupun yang akan datang untuk berbagai golongan mayarakat" .

Ilmu ekonomi juga menganalisis adanya besarnya biayabiaya dan keuntungan yang terjadi karena adanya perbaikan dalam pola alokasi sumber-sumber. Demikian juga hukum dan ekonomi, dua hal yang tidak dapat dipisahkan, sebab dua hal itu saling melengkapi seperti dua sisi mata uang. Hukum ekonomi merupakan kajian tentang hukum yang berkaitan dengan ekonomi secara interdisipliner dan multidemensional.

Menurut Rachmat Soemitro, "hukum ekonomi adalah keseluruhan norma-norma yang dibuat oleh pemerintah atau penguasa sebagai satu personifikasi dari masyarakat yang mengatur kehidupan ekonomi dimana kepentingan individu dan masyarakat saling berhadapan" 7 .

Untuk memperjelas pengertian ekonomi syari'ah secara makro, maka ada beberapa ahli dan pakar ekonomi syari'ah sebagai berikut :

1. Muhammad Abdul Manan, yang dimaksud ekonomi syari'ah adalah ilmu pengetahu sosial yang mempelajari masalahmasalah ekonomi rakyat yang diilhami oleh nilai-nilai Islam. ${ }^{8}$

2. Muhammad Nejatullah, yang dimaksud ekonomi syari'ah adalah respons pemikir Islam (Muslim) terhadap tantangan ekonomi pada masa tertentu yang bersumber dari al-Qur'an, al-Hadits, al-Aqlu, dan al-Ijtihad. ${ }^{9}$

3. Munawar Iqbal, yang dimaksud ekonomi syari'ah adalah "sebuah dispilin ilmu yang mempunyai akar dalam syari'ah Islam. Islam memandang wahyu Allah sebagai sumber ilmu pengetahuan yang paling utama. Prinsip-prinsip dasar yang dicantumkan dalam al-Qur'an dan al-Hadits adalah batu ujian untuk menilai teori-teori baru berdasarkan doktrin-doktrin

${ }^{6}$ Ely Musykuroh, Pengantar Teori Ekonomi, Pendekatan pada Teori Ekonomi Makro Islam, (Panoraga: STAIN Panoraga Press, 2008), hlm. 8

${ }^{7}$ Rachmat Soemitro, Hukum Ekonomi (Economic Law), Kertas Kerja pada Simposium Pembinaan Hukum Nasional, BPHN, (Jakarta: UI Press, 2008), hlm. 18

8 Muhammad Abdul Manan, Islamic Economic, Theory and Practice, (Cambridge: Hourder and Stoughton, Ltd), hlm. 18

9 Muhammad Najetullah Siddiqi, Rule of the State in the Ekonomic, In Islamic Perspective, (UK. The Islamic Foundation, 1992), hlm. 69. 
Prinsip Dasar Rancang Bangun... Oleh: Jamaluddin

ekonomi syari'ah. Dalam hal ini himpunan hadits merupakan sebuah buku sumber yang sangat berguna" 10

Dari beberapa pengertian ekonomi syari'ah di atas dapat diketahui bahwa ekonomi syari'ah bukan hanya mengkaji tentang persoalan nilai, tetapi juga dalam bidang kajian keilmuan. Keterpaduan antara ilmu dan nilai menyajikan ekonomi syari'ah sebagai konsep yang integral dalam membangun keutuhan hidup bermasyarakat. Ekonomi syari'ah sebagai ilmu menjadikan ekonomi syari'ah dapat dicerna dengan metode-metode ilmu pengetahuan pada umumnya, sedangkan ekonomi syari'ah sebagai nilai menjadikan ekonomi syari'ah relevan dengan fitrah manusia.

\section{Rancang Bangun Ekonomi Syari'ah}

Para pakar dan ahli ekonomi syari'ah yang telah merumuskan prinsip-prinsip ekonomi syari'ah, walaupun ada beberapa perbedaan dalam struktur dan tata urutanya, tetapi secara subtansinya sama dengan yang lainya. Ada beberapa prinsip dasar terhadap rancang bangun ekonomi syari'ah. Muhammad mengatakan bahwa bangunan ekonomi syari'ah diletakkan pada 5 (lima) fondasi, yaitu : Ketuhanan (Ilahiah), keadilan $(a l-A d l)$, kenabian (an-Nubuwah), pemerintahan (alKhalifah), dan hasil/kuntungan (al-Ma'ad). Kelima fondasi tersebut dapatnya menjadikan aspirasi dalam menyusun teoriteori ekonomi syari'ah. ${ }^{1}$

\section{Nilai Ketuhanan (Ilahiah)}

Seluruh aktivitas ekonomi harus berangkat dari filosofi dasar yang bersumber dari Allah swt. dengan tujuan utama semata-semata untuk mencari ridha Allah semata (limardhatillahi) yang meliputi permodalam, proses produksi, distribusi, konsumsi dan pemasaran harus senantiasa dikaitkan dengan nilai-nilai Ilahi dan harus selaras dengan tujuan yang telah ditetapkan oleh syara' (hukum Islam) Allah swt. karena sesungguhnya dalam alam semesta ini adalah

10 Munawar Iqbal, Economic Teaching of Prophet Muhammad, (May Peace Upon Rim, 1999), hlm. 22

${ }_{11}$ Muhammad, Ekonomi Makro dalam Perspektif Islam, (Yogyakarta: Fakultas Hukum UGM, 2004), hlm. 95. 
milik Allah swt. manusia hanya pemegang amanah Allah swt. sebagaimana firman Allah dalam surat Najm, 31 sebagai berikut :

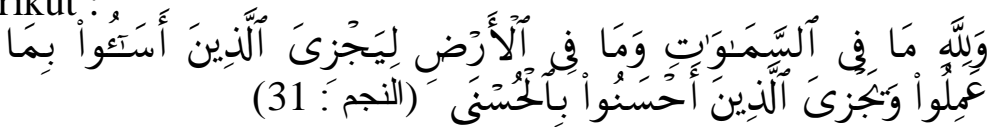

Terjemahanya: "dan hanya kepunyaan Allah-lah apa yang ada di langit dan apa yang ada di bumi supaya Dia memberi balasan kepada orangorang yang berbuat jahat terhadap apa yang telah mereka kerjakan dan memberi balasan kepada orang-orang yang berbuat baik dengan pahala yang lebih baik (surga)",12 (QS. Al-Najm, 31)

2. Nilai Keadilan $(a l-A d l)$

Salah satu prinsip yang sangat penting dalam ekonomi syari'ah adalah keadilan. Perilaku adil tidak hanya berdasarkan kepada al-Qur'an dan al-Hadits, tetapi didasarkan pula pada pertimbangan hukum alam, yang didasarkan pula pada keseimbangan dan keadilan. Keadilan dalam ekonomi syari'ah dapat diterapkan secara menyeluruh, antara lain dalam menentukan harga, kualitas produk, perlakuan terhadap para pekerja dan dampak dari kebijakan ekonomi yang dikeluarkan.

Penegakan keadilan dan usaha mengeliminasi segala bentuk diskriminasi menjadi prioritas utama, sebagaimana firman Allabh dalam surat al-Maidah ayat 8 sebagai berikut :

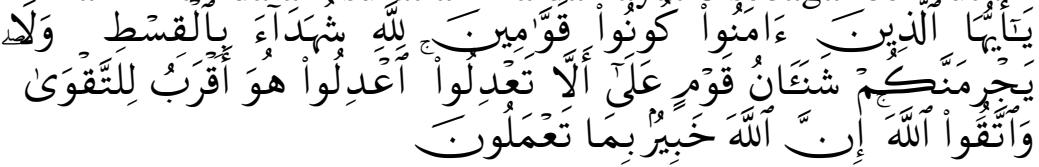

Terjemahnya: "Wahai orang-orang yang beriman hendaklah kamu jadi orang-orang yang selalu menegakkan (kebenaran) karena Allah, menjadi saksi dengan adil. dan janganlah sekali-kali kebencianmu terhadap sesuatu kaum, mendorong kamu untuk berlaku tidak

12 Departemen Agama RI., al-Qur'an dan Terjemahnya, (Jakarta:

Tim Pembinaan Kitab Suci al-Qur'an, 1984), hlm. 
Prinsip Dasar Rancang Bangun... Oleh: Jamaluddin

adil. Berlaku adillah, karena adil itu lebih dekat kepada takwa. dan bertakwalah kepada Allah, Sesungguhnya Allah Maha mengetahui apa yang kamu kerjakan"13 (QS. Al-Ma'idah, 8)

Prinsip keadilan sebagaimana yang ditetapkan oleh Allah swt. haruslah dilaksanakan dalam segala dimensi kehidupan, apabila hal tersebut tidak dilaksanakan, maka penindasan, kekerasan, kekejaman, dan eksploitasi akan terjadi sepanjang masa.

Keadilan adalah ruh dari penerapan nilai-nilai kemanusiaan, keharmonisan, dan kesejahteraan dalam kehidupan manusia. dengan demikian dalam Islam berarti tidak berbuat dholim kepada sesama manusia, dan bukan berarti "sama rata sama rasa". Adil dalam Islam adalah menempatkan sesuatu pada tempatnya (wad'u al-syai' ala makanihi). ${ }^{14}$

3. Nilai Kenabian (al-Nubuwah)

Nabi Muhammad saw. adalah sebagai sentra pembawa syari' at (hukum) Islam di dunia ini. Kenabian bukan martabat dan derajat yang diperoleh melalui usaha (warisan). Allah mempunyai hak prerogatif untuk memilih umat-Nya untuk menjadi Nabi atau Rasul. Nabi Muhammad memiliki kepribadian yang agung dan sempurna (perfect personality) dengan karakter utamanya as-Shiddiq (kebenaran), alAmanah (terpercaya), Fathonah (cerdas), at-Tabligh (komunikatif). Sifat-sifat di atas sangat diperlulan, terutama dalam menumbuhkan sifat profesionalisme dalam menjalankan tugas amanah yang diembanya.

4. Nilai Pemerintahan (al-Khalifah)

Peran pemerintah/negara (khalifah) sangat diperlukan dalam instrumen dan fungsionalisasi nilai-nilai ekonomi syari'ah dalam aspek legal, perencanaan dan pengawalanya pengalokasian distribusi sumber-sumber dan dana.

13 Ibid,

14 Quraisy Shihab,

Volume 26 Nomor 1 Januari 2015 
Oleh karena itu pemerintah sebagai pemilik manfaat sumber-sumber ekonomi yang bersifat publik, produksi dan distribusi serta sebagai lembaga pengawasan kehidupan ekonomi, maka pemerintah berhak campur tangan dalam kegiataan ekonomi yang dilaksanakan oleh individu maupun masyarakat. Ikut campur tangan bukan berarti pemerintah berhak monopoli segala sektor ekonomi negara.

Yusuf al-Qardhawi menjelaskan bahwa tugas negara adalah mengubah pemikiran menjadi amal perbuataan, memindahkan moralitas kepada praktik-praktik konkret. Tugas negara juga harus me-monitoring pelaksanaan program kerja dan kinerja negara ${ }^{15}$

5. Nilai hasil/keuntungan ( $\left.a l-M a{ }^{\prime} a d\right)$

Tujuan ekonomi syari'ah adalah sebagaimana firman Allah surat al-Qashash ayat-27 sebagai berikut :

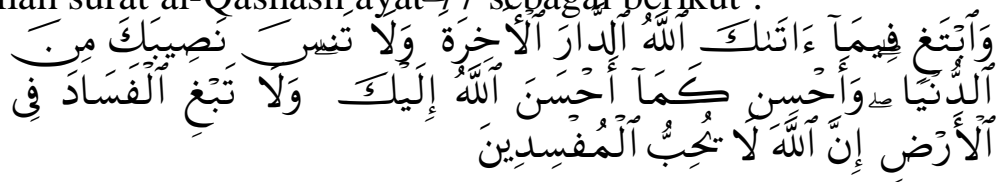

Terjemahnya: "Dan carilah pada apa yang telah dianugerahkan Allah kepadamu (kebahagiaan) negeri akhirat, dan janganlah kamu melupakan bahagianmu dari (kenikmatan) duniawi dan berbuat baiklah (kepada orang lain) sebagaimana Allah telah berbuat baik, kepadamu, dan janganlah kamu berbuat kerusakan di (muka) bumi. Sesungguhnya Allah tidak menyukai orangorang yang berbuat kerusakan"16 (QS. AlQashash. 77).

Ayat di atas, Allah memperingatkan kepada manusia bahwa kehidupan dunia hanya bersifat sementara dan ada kehidupan di akhirat nanti, dan di sanalah manusia akan

15 Yusuf al-Qardhawi, Ijtihad Komtemporer, Kodev Etik dan Berbagai Penyimpangan, terj. Abu Barzani, (Surabaya: Risalah Gusti, 2000), hlm. 13 \& hlm. 83

16 Departemen Agama RI., al-Qur'an dan Terjemahnya, 
Prinsip Dasar Rancang Bangun... Oleh: Jamaluddin

mendapatkan kebahagiaan, kesenangan, dan kesempurnaan hidup apabila ia berbuat kebajikan ketika hidup di dunia.

Karakteristik ekonomi syari'ah mengakui ada dua tujuan yang harus dicapai oleh setiap orang sebagai pelaksana ekonomi, yaitu tujuan hidup dunia dan akhirat. Dalam ekonomi syari'ah dalam segala bentuk aktivitasnya harus memiliki nilai ganda dan harus berimplikasi pada keseriusan berusaha, karena adanya tanggung jawab dunia dan akhirat. Pelaku ekonomi syari'ah, baik individu maupun masyarakat (negara) harus memiliki karakteristik time horizon agar tujuan ekonomi (syari'ah) dapat tercapai dengan baik. Tujuan ini adalah kesejahteraan dunia (profit oriented) dan kesejahteraan di akhirat (falakh oriented) ${ }^{17}$

Sesungguhnya prinsip utama yang dianut oleh ekonomi syari'ah dan lembaga keuangan Syari'ah dalam menjalankan aktivitas harus terhindar dari usahanya :

1. Bebas dari "Maghrib"

a. Maysir (spekulasi), secara bahasa artinya "Judi". Secara umum "mengundi nasib", dan setiap kegiatan yang sifatnya untung-untungan (spekulasi). Dalam alQur'an kata Maysir disebut sebanyak 44 kali, diantaranya surat al-Baqarah ayat 219 sebagai berikut:

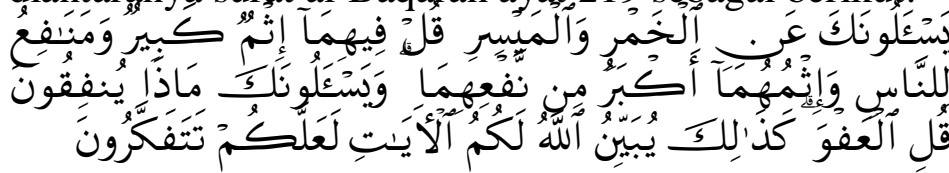

Terjemahnya: "Mereka bertanya kepadamu tentang khamar (segala minuman yang memabukkan) dan judi. Katakanlah: "Pada keduanya terdapat dosa yang besar dan beberapa manfaat bagi manusia, tetapi dosa keduanya lebih besar dari manfaatnya". dan mereka bertanya kepadamu apa yang mereka nafkahkan. Katakanlah: "yang lebih dari keperluan." Demikianlah Allah

17 Abdul Manan, Hukum Ekonomi Syari'ah Perspektif Kewenangan Peradilan Agama, (Jakarta: PT Fajar Inerpratama Mandiri, 2012), hlm.16 Volume 26 Nomor 1 Januari 2015 
menerangkan ayat-ayat-Nya kepadamu supaya kamu berfikir" (QS. AlBaqarah, 219).

Demikian juga dalam surat al-Ma'idah ayat : 90-91 sebagai berikut :

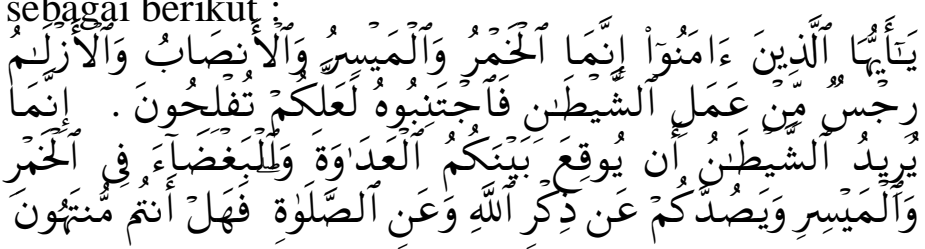

Terjemahnya: "Wahai orang-orang yang beriman, Sesungguhnya (meminum) khamar, berjudi, (berkorban untuk) berhala, mengundi nasib dengan panah, adalah termasuk perbuatan syaitan. Maka jauhilah perbuatan-perbuatan itu agar kamu mendapat keberuntungan. (90). Sesungguhnya syaitan itu bermaksud hendak menimbulkan permusuhan dan kebencian di antara kamu lantaran (meminum) khamar dan berjudi itu, dan menghalangi kamu dari mengingat Allah dan sembahyang; Maka berhentilah kamu (dari mengerjakan pekerjaan itu) (91).

b. Gharar, secara bahasa artinya "Menipu, memperdaya, dan ketidakpastian". Gharar adalah sesuatu yang memberdayakan orang lain dalam bentuk harta, kemegahan, jabatan, syahwat (keinginan), dan lain sebagainya. Dalam al-Qur'an kata Gharar disebut sebanyak 27 kali. Diantaranya surat Ali Imran ayat 185 sebagai berikut :

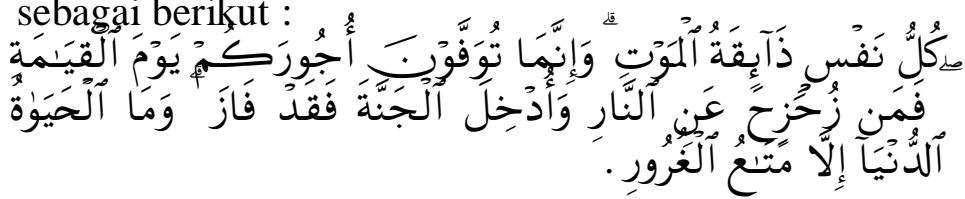

Artinya: "tiap-tiap yang berjiwa akan merasakan mati. dan Sesungguhnya pada hari kiamat sajalah disempurnakan pahalamu. Barangsiapa 
Prinsip Dasar Rancang Bangun... Oleh: Jamaluddin

dijauhkan dari neraka dan dimasukkan ke dalam syurga, maka sungguh ia telah beruntung, kehidupan dunia itu tidak lain hanyalah kesenangan yang memperdayakan" (QS. Ali Imran, 185).

c. Haram, secara bahasa berarti "Larangan dan Penegasan". Larangan dapat timbul karena beberapa kemungkinan. Dilarang oleh Allah dan juga karena pertimbangan akal. Kata haram di dalam al-Qur'an disebut sebanyak 38 kali, diaantaranya surat al-Baqarah ayat 173 sebagai berikut:

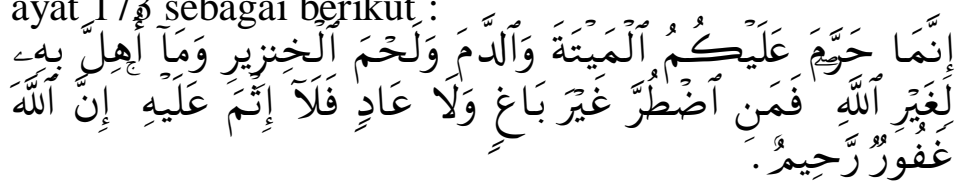

Terjemahnya: "Sesungguhnya Allah hanya mengharamkan bagimu bangkai, darah, daging babi, dan binatang yang (ketika disembelih) disebut (nama) selain Allah[108]. tetapi Barangsiapa dalam Keadaan terpaksa (memakannya) sedang Dia tidak menginginkannya dan tidak (pula) melampaui batas, Maka tidak ada dosa baginya. Sesungguhnya Allah Maha Pengampun lagi Maha Penyayang" (QS. Al-Baqarah, 173).

Haram juga menurut ayat ini daging yang berasal dari sembelihan yang menyebut nama Allah tetapi disebut pula nama selain Allah.

d. Riba, secara bahasa berarti "bertambah dan tumbuh". Kata riba dengan berbagai bentuknya disebutkan dalam al-Qur'an sebanyak 20 kali, diantaranya surat Ali Amron, ayat 130 sebagai berikut :

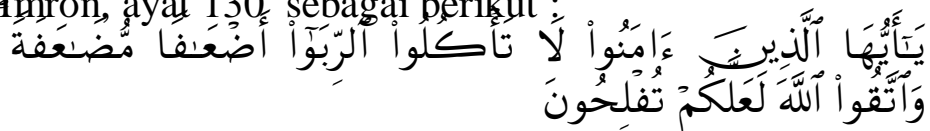

Terjemahnya: "Wahai orang-orang yang beriman, janganlah kamu memakan Riba dengan berlipat ganda dan bertakwalah kamu kepada Allah 
supaya kamu mendapat keberuntungan"

(QS. Ali Imron, 130).

e. Bathil, secara bahasa artinya "Batal, tidak sah", sebagaimana disebutkan dalam surat al-Baqarah ayat 188 sebagai berikut :

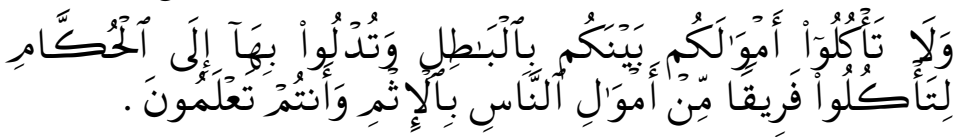

Terjemahnya: "Dan janganlah sebahagían kamu memakan harta sebahagian yang lain di antara kamu dengan jalan yang bathil dan (janganlah) kamu membawa (urusan) harta itu kepada hakim, supaya kamu dapat memakan sebahagian daripada harta benda orang lain itu dengan (jalan berbuat) dosa, Padahal kamu mengetahui” (QS. Al-Baqarah, 188)

2. Memperoleh keuntungan yang Sah.

3. Menyalurkan Zakat, Infaq dan Shadaqah. 
Prinsip Dasar Rancang Bangun... Oleh: Jamaluddin

\section{DAFTAR PUSTAKA}

al-Qardhawi, Yusuf. Ijtihad Komtemporer, Kodev Etik dan Berbagai Penyimpangan, terj. Abu Barzani, (Surabaya: Risalah Gusti, 2000)

Arifin, Jaenal. Jejak Langkah Peradilan Agama di Indonesia, (Jakarta: PT Khaarisma Putra Utama, 2013)

Departemen Agama RI., al-Qur'an dan Terjemahanya, (Jakarta: Tim Pengadaan Kitab Suci al-Qur'an, 1984)

Iqbal, Munawar. Economic Teaching of Prophet Muhammad, (May Peace Upon Rim, 1999)

M. Yusuf \& Wiroso, Pengantar Ekonomi dan Bisnis Syari'ah, Edisi 2, (Jakarta: Mitra Wacana Media, 2011)

Manan, Muhammad Abdul, Islamic Economic, Theory and Practice, (Cambridge: Hourder and Stoughton, Ltd)

Manan, Abdul. Hukum Ekonomi Syari'ah Perspektif Kewenangan Peradilan Agama, (Jakarta: PT Fajar Inerpratama Mandiri, 2012)

Muhammad, Ekonomi Makro dalam Perspektif Islam, (Yogyakarta: Fakultas Hukum UGM, 2004)

Musykuroh, Ely. Pengantar Teori Ekonomi, Pendekatan pada Teori Ekonomi Makro Islam, (Panoraga: STAIN Panoraga Press, 2008)

Soemitro, Rachmat. Hukum Ekonomi (Economic Law), Kertas Kerja pada Simposium Pembinaan Hukum Nasional, BPHN, (Jakarta: UI Press, 2008)

Siddiqi, Muhammad Najetullah. Rule of the State in the Ekonomic, In Islamic Perspective, (UK. The Islamic Foundation, 1992) 